\title{
Regional anaesthesia in a Duchenne muscular dystrophy patient for upper extremity amputation
}

\author{
Duchenne musküler distrofili hastada üst ekstremite \\ amputasyonu için bölgesel anestezi
}

\author{
Mehmet Illke BÜGET,1 ilker EREN, ${ }^{2}$ Süleyman KÜÇÜKAY'
}

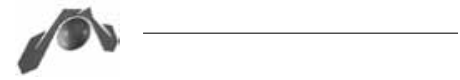

\begin{abstract}
Summary
Duchenne muscular dystrophy (DMD) is the most common of the neuromuscular disorders. DMD is usually a challenge for the anaesthesiologist, with poor cardiac function, a high risk of developing rhabdomyolysis, and the probable life-threatening complications of general anaesthesia. To avoid possible morbidity associated with general anaesthesia, we applied a supraclavicular blockade. In this report, we present a 17-year-old DMD patient with a massive rhabdomyosarcoma, for whom a left arm amputation was indicated. In the post-operative period, a malignant hyperthermia-like reaction occurred, which resolved in a short time. We suggest a regional blockade as a safer alternative to general anaesthesia for the management of high risk DMD patients during orthopedic procedures.
\end{abstract}

Key words: Amputation; Duchenne; muscular dystrophy; regional anaesthesia.

\begin{abstract}
Özet
Duchenne musküler distrofisi, (DMD) nöromusküler hastaliklar arasinda en sık görülen rahatsızlıtır. Ciddi kardiyak rahatsizlıklar, yüksek rabdomyoliz gelişme ibtimali ve genel anestezinin bayati risk olasiliğı yüksek komplikasyonlarıla, DMD, anestezistler için genellikle sıkıntı oluşturmaktadır. Genel anesteziyle ilşkili mubtemel morbiditeden kaçınmak için bastamızda supraklaviküler blok uyguladik. Bu raporda, masif rabdomyosarkomu olan ve amputasyon endikasyonu mecut olan, 17 yaşındaki Duchenne'li bir bastayı sunmayı amaçladık. Ameliyat sonrası dönemde, kısa süre içinde geçen, malign bipertermi benzeri bir reaksiyon gelişimini tespit ettik. Biz ortopedik cerrabi geçirecek DMD'li hastalarda genel anesteziye güvenli bir alternatif olarak rejyonel anestezi uygulamaları önermekteyiz.
\end{abstract}

Anahtar Kelimeler: Amputasyon; Duchenne; musküler distrofi; rejyonel anestezi.

\section{Introduction}

Duchenne muscular dystrophy (DMD) is the most common disease among neuromuscular disorders. It is X linked and seen one in every 3500 male. ${ }^{[1]}$ Death most frequently occurs in the second decade mostly due to respiratory $(90 \%)$ and cardiac $(10 \%)$ complications. ${ }^{[1]}$ Respiratory failure, pulmonary aspiration, atelectasis, pneumonia, congestive heart failure, and cardiac arrhythmia are the possible complications associated with DMD during the operation period. The limited ability of the patients to augment cardiac output, in order to respond sufficiently to surgical stress, is a danger to adequate oxygen delivery. ${ }^{[2]}$ Probable blood losses and fluid shifts during major surgeries also attenuate cardiac output and sufficient oxygen delivery. ${ }^{[3]}$ DMD patients are at constant

\footnotetext{
'Department of Anesthesiology, Istanbul University Istanbul Faculty of Medicine, Istanbul, Turkey;

${ }^{2}$ Department of Orthopaedics and Traumatology, Istanbul University Istanbul Faculty of Medicine, Istanbul, Turkey

Istanbul Üniversitesi Istanbul Tıp Fakültesi, Anesteziyoloji Anabilim Dalı, Istanbul;

Istanbul Üniversitesi İstanbul Tıp Fakültesi, Ortopedi ve Travmataloji Anabilim Dalı, İstanbul

Submitted (Başvuru tarihi) 07.02.2013 Accepted after revision (Düzeltme sonrası kabul tarihi) 14.02.2013
}

Correspondence (İletişim): Dr. Mehmet İlke Büget. İstanbul Üniversitesi İstanbul Tıp Fakültesi, Ortopedi ve Travmataloji Anabilim Dalı, Çapa, Fatih, İstanbul, Turkey.

Tel: +90 - 212 - 4142000 / 31742 e-mail (e-posta): mbuget@yahoo.com 
risk of encountering complications within the operation period. ${ }^{[4,5]}$ For that reason, the management of a DMD patient always requires multidisciplinary approach.

We present a 17 year old Duchenne patient with a huge rhabdomyosarcoma in his left arm (Figure $1 \mathrm{a}, \mathrm{b})$. In this patient, amputation of the arm was indicated surgically and we decided to apply a supraclavicular blockade for the anesthesia.

\section{Case Report}

A 17 year old DMD patient was presented in this
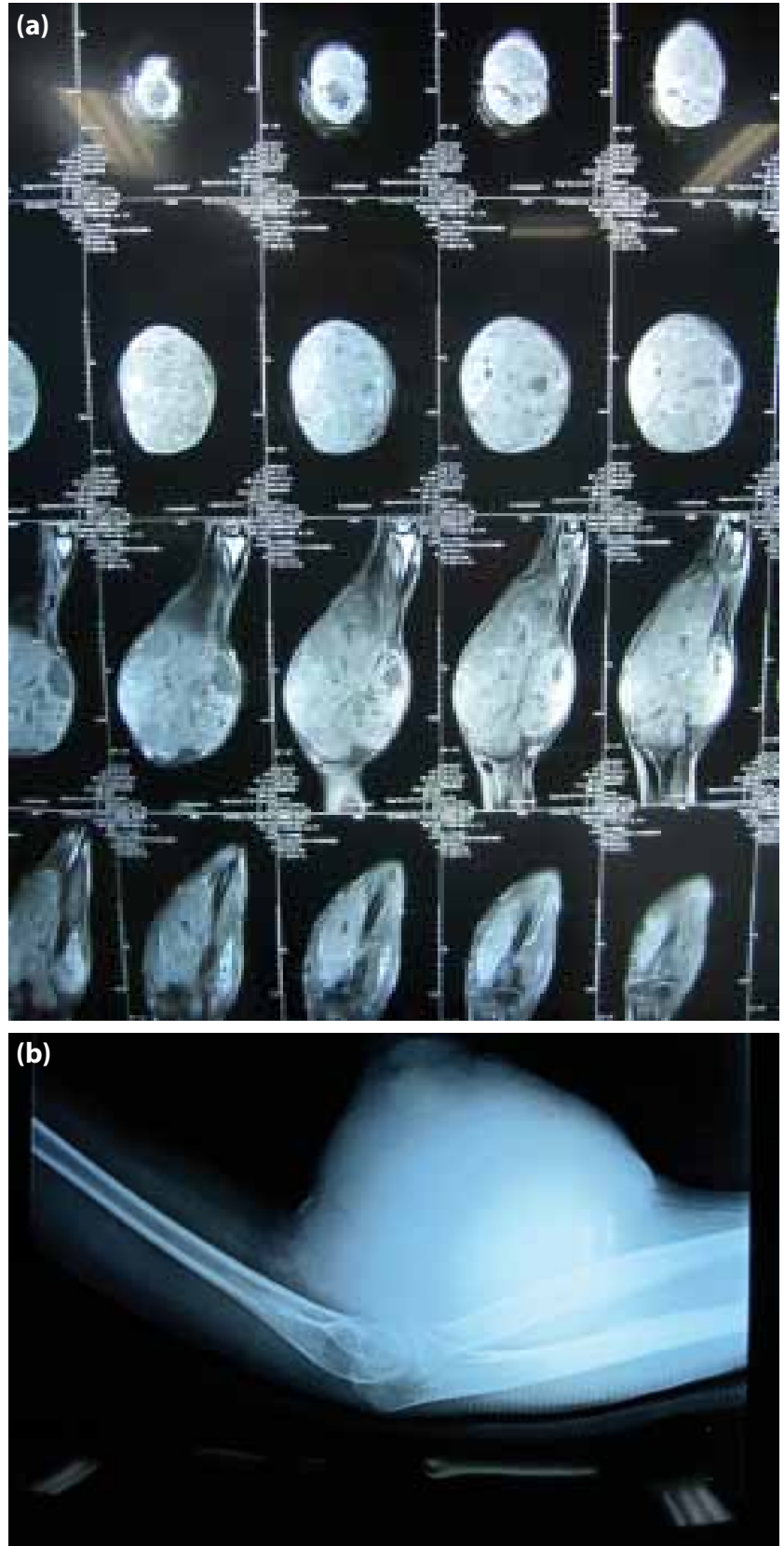

Figure 1. (a, b) Radiological images of the rhabdomyosarcoma. report. He was operated for a massive rhabdomyosarcoma (Figure 2a). In his echocardiography, dilated cardiomyopathy, mitral regurgitation and ejection fraction of $23 \%$ were detected. His pulmonary function tests revealed a FEV1: 82\%, FVC: 68\%, and FEV1/FVC: $116 \%$. In his blood testing, creatinin kinase $(\mathrm{CK})$ was $1420 \mathrm{U} / \mathrm{L}$ and electrolyte levels were within the normal range. We decided to perform a supraclavicular block with a nerve stimulator for anesthesia of the patient. A skin wheal was raised with $1 \%$ lidocaine. After appropriate twitches for the brachial plexus were elicited, $30 \mathrm{ml} 0.5 \%$ bupivacaine without any additives was injected for the block. Twenty minutes later, motor and sensory blockade was satisfactory in the entire arm. He was breathing spontaneously with a face mask $\left(\mathrm{SpO}_{2} 99 \%\right)$, with a heart rate (HR) of $88 / \mathrm{min}$ and blood pressure (BP) of 110/77 $\mathrm{mmHg}$. Following the confirmation of block success, the operation was initiated. The patient was prepared and draped in a standard fashion, leaving the entire upper extremity free. In order to avoid contamination from actively bleeding exulcerated mass (Figure 2b), arm distal to the elbow covered. Dissection was performed leaving equal anterior and posterior skin flaps. Brachial artery and vein were doubly ligated. Median, ulnar and radial nerves were transected from a more proximal level and let retract. All muscular tissues were severely atrophic, almost without any contractible part. Bone was divided with an oscillating saw, and rasped to achieve smooth end. Leaving a drain inside, posterior and anterior flaps were sutured and skin was closed. The total duration of the operation was 2 hours and we did not observe any problems within this period.

He was taken into ICU for close monitoring, breathing spontaneously, with $\mathrm{SpO}_{2}: 100 \%, \mathrm{BP}$ : $100 / 70 \mathrm{mmHg}$ and HR: $85 / \mathrm{min}$. In the third post-operative hour fever of $39^{\circ} \mathrm{C}$ was detected in our patient. A face mask was applied for oxygen; paracetamol $1 \mathrm{~g}$ was administered intravenously, whereas cold compression was applied immediately. His blood gas analysis revealed values within normal ranges. Acidosis, hyperkalemia and $\mathrm{CO}_{2}$ rise were not present. Creatine level, urine output and blood count were also normal. Within 3 hours, the fever declined gradually and tachycardia also disappeared. 

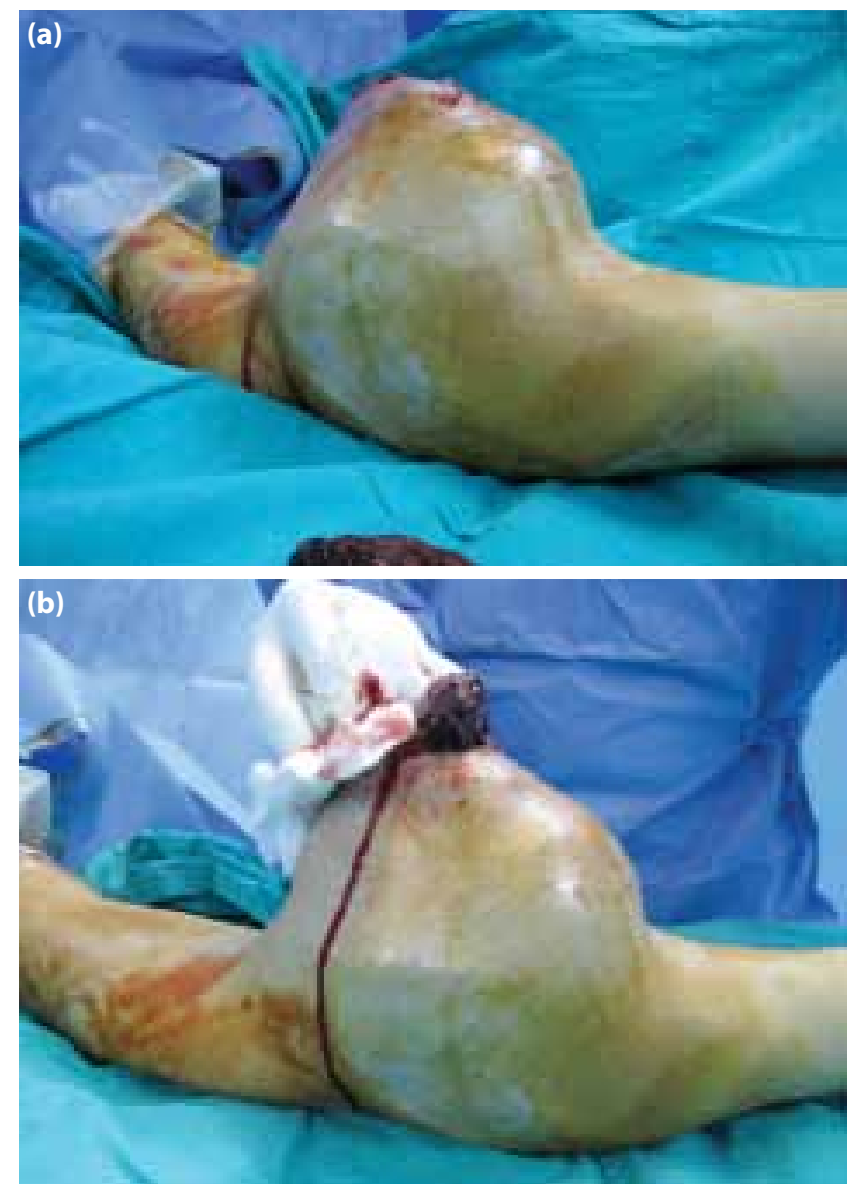

Figure 2. (a) Huge rhabdomyosarcoma. (b) Bleeding mass.

His CK levels were elevated to 5420 U/L. In the second post-operative day, CK levels decreased to 2110 $\mathrm{U} / \mathrm{L}$ and he did not demonstrate any symptoms. He was discharged in the third post-operative day.

\section{Discussion}

DMD is caused by an X-chromosome linked recessive mutation that prevents normal formation of a muscle-stabilizing protein, named dystrophin and loss of dystrophin leads to muscular dystrophy. ${ }^{[6]}$

In this report, our patient's left arm was amputated because of a massive rhabdomyosarcoma occupying his arm. Considering his poor cardiac function and increased risk of rhabdomyolysis, we decided to perform a supraclavicular blockade instead of general anesthesia.

In the literature, there exist many cases of complications due to general anesthesia ${ }^{[7-9]}$ in DMD patients. Exposure to volatile anesthetic agents can induce rhabdomyolysis and malignant hyperthermia-like reactions, which in turn may cause cardiac arrest, even death. ${ }^{[6,10]}$ The perioperative use of succinylcholine is also contraindicated because of the risk of rhabdomyolysis, hyperkalemia, and cardiac arrest. ${ }^{[10]}$ In order to avoid these risks, succinylcholine should not be used; and volatile anesthetics should be used caution if necessary. Whenever possible, potential trigger free anesthetics, such as total intravenous anesthesia (TIVA) and a 'clean' anesthesia machine should be used. ${ }^{[11]}$ We thought regional anesthesia can be a relatively safe option compared to general anesthesia, provided that the surgical site is appropriate for the technique. Çalışkan et al reported an uneventful spinal anesthesia for a DMD patient and suggested regional anesthesia whenever possible. ${ }^{[12]}$ Unlike their experience which ended uneventfully, our case developed malign hyperthermia $(\mathrm{MH})$ like reaction in the third post-operative hour. For oxygen delivery, a face mask was used, and this face mask circuit was taking its roots from the anesthesia machine. Although the machine was cleaned for $30 \mathrm{~min}$ before the operation, a residue of an agent might cause this reaction, as the amount of volatile residue that can cause the reaction is unknown. ${ }^{[1]}$ In his report Hayes et al. categorized the $\mathrm{MH}$ like clinical presentations into three groups: Acute onset of hyperkalemic cardiac arrest, postoperative rhabdomyolysis without cardiac arrest and gradual rise in temperature and heart rate group. ${ }^{[11]}$ Our case can be an example of the latter group, although our case differs in terms of the regional anesthesia applied and anesthetic agents avoided. In the literature, 7 patients had tachycardia and hyperthermia occurred within a few hours of anesthesia and resolved spontaneously. ${ }^{[13]}$

In this case, we used a nerve stimulator to determine the injection point, because there is no evidence in the literature that stimulation of a muscle can raise extracellular potassium levels. ${ }^{[14]}$ Thus, we did not notice any alterations in our patient's potassium levels during the follow up.

DMD is associated with the weakness of the diaphragm, intercostal muscles, and other respiratory accessory muscles, depending on this restrictive pulmonary insufficiency and a progressive decline in lung capacity develops. ${ }^{[15]}$ Beside, DMD patients are at risk of respiratory failure which is caused by 
muscle weakness leading to hypoventilation and insufficient cough leading to ineffective airway secretion clearance. ${ }^{[16]}$ Our major concern with supraclavicular block was the possibility of developing hemi-diaphragmatic paralysis (HDP) after the block, which occurs unpredictably and makes the block not recommended in patients who are not capable of tolerating a $30 \%$ decline in pulmonary function. ${ }^{[17]}$ In a study evaluating HDP after supraclavicular blockade, the author demonstrated a lower incidence of HDP when compared to interscalene blockade $\left(50 \%\right.$ and $100 \%$, respectively). ${ }^{[18]}$ Although hemidiaphragmatic paresis may develop in some patients after supraclavicular block, its duration was shorter than observed following sensory and motor block and was not associated with a significant respiratory impairment in patients without any co-morbidity. ${ }^{[18]}$ We used supraclavicular blockade in this case because it covered the surgical field and had a lower incidence of HDP than which the interscalene approach had. Although DMD patients have generally serious restrictive pulmonary impairment, our patient's pulmonary reserve was sufficient for a 30\% decline. In our case, we did not detect any respiratory impairment and it was unlikely that the patient had HDP.

Pneumothorax was another possible complication for the supraclavicular blockade. In literature, the overall incidence of pneumothorax associated with supraclavicular block was between 0.5\%-6\%, when the needle was guided towards the apical pleura. ${ }^{[17]}$ However, these numbers are slightly overemphasized, given that different approaches such as the plumb-bob and subclavian perivascular approaches diminish the risk of pneumothorax significantly. ${ }^{[19]}$ Consistent with previous findings, we did not observe pneumothorax in our patient after our blockade.

Among DMD patients, cardiomyopathy is common. It is suggested that, by the second decade, (80-90\%) most of the patients will have a dilated cardiomyopathy detected in echocardiography and half of them will have clinical heart failure. ${ }^{[20]}$ DMD patients are at increased risk for perioperative congestive heart failure and cardiac arrhythmia; they have a limited ability to increase cardiac output in response to stress. Fluid boluses or blood transfu- sions may cause intravascular fluid imbalance. ${ }^{[15]}$ In our case, although our patient had a serious heart failure, peripheral nerve blockade did not cause any negative hemodynamic effects, as expected. Careful fluid management reduced the risk of fluid imbalance.

Although regional anesthesia is a good alternative to general anesthesia in DMD patients, our case demonstrated a possible $\mathrm{MH}$ - like reaction, even with regional anesthesia. Close monitoring and strict follow up are essential both in the perioperative and postoperative period.

\section{Conflict-of-interest issues regarding the author- ship or article: None declared.}

\section{Peer-rewiew: Externally peer-reviewed.}

\section{References}

1. Morris P. Duchenne muscular dystrophy: a challenge for the anaesthetist. Paediatr Anaesth 1997;7(1):1-4. CrossRef

2. American Academy of Pediatrics Section on Cardiology and Cardiac Surgery. Cardiovascular health supervision for individuals affected by Duchenne or Becker muscular dystrophy. Pediatrics 2005;116(6):1569-73. CrossRef

3. Noordeen $\mathrm{MH}$, Haddad FS, Muntoni F, Gobbi P, Hollyer JS, Bentley G. Blood loss in Duchenne muscular dystrophy: vascular smooth muscle dysfunction? J Pediatr Orthop B 1999;8(3):212-5. CrossRef

4. Girshin M, Mukherjee J, Clowney R, Singer LP, Wasnick J. The postoperative cardiovascular arrest of a 5-year-old male: an initial presentation of Duchenne's muscular dystrophy. Paediatr Anaesth 2006;16(2):170-3. CrossRef

5. Schmidt GN, Burmeister MA, Lilje C, Wappler F, Bischoff P. Acute heart failure during spinal surgery in a boy with Duchenne muscular dystrophy. Br J Anaesth 2003;90(6):800-4.

6 Gurnaney H, Brown A, Litman RS. Malignant hyperthermia and muscular dystrophies. Anesth Analg 2009;109(4):10438. CrossRef

7. Irwin MG, Henderson M. Cardiac arrest during major spinal scoliosis surgery in a patient with Duchenne's muscular dystrophy undergoing intravenous anaesthesia. Anaesth Intensive Care 1995;23(5):626-9.

8. Smelt WL. Cardiac arrest during desflurane anaesthesia in a patient with Duchenne's muscular dystrophy. Acta Anaesthesiol Scand 2005;49(2):267-9. CrossRef

9. Reid JM, Appleton PJ. A case of ventricular fibrillation in the prone position during back stabilisation surgery in a boy with Duchenne's muscular dystrophy. Anaesthesia 1999;54(4):364-7. CrossRef

10. Birnkrant DJ. The American College of Chest Physicians consensus statement on the respiratory and related management of patients with Duchenne muscular dystrophy undergoing anesthesia or sedation. Pediatrics 2009;123 Suppl 4:242-4. CrossRef

11. Hayes J, Veyckemans F, Bissonnette B. Duchenne muscular dystrophy: an old anesthesia problem revisited. Paediatr An- 
aesth 2008;18(2):100-6.

12. Caliskan E, Sener M, Kocum A, Aribogan A. Duchenne muscular dystrophy: how I do it? Regional or general anesthesia? Paediatr Anaesth 2009;19(6):624-5. CrossRef

13. Larsen UT, Juhl B, Hein-Sörensen O, de Fine Olivarius B. Complications during anaesthesia in patients with Duchenne's muscular dystrophy (a retrospective study) Can J Anaesth 1989;36(4):418-22. CrossRef

14. Ames WA, Hayes JA, Crawford MW. The role of corticosteroids in Duchenne muscular dystrophy: a review for the anesthetist. Paediatr Anaesth 2005;15(1):3-8. CrossRef

15. Birnkrant DJ, Panitch HB, Benditt JO, Boitano LJ, Carter ER, Cwik VA, et al. American College of Chest Physicians consensus statement on the respiratory and related management of patients with Duchenne muscular dystrophy undergoing anesthesia or sedation. Chest 2007;132(6):1977-86. CrossRef
16. Kravitz RM. Airway clearance in Duchenne muscular dystrophy. Pediatrics 2009;123 Suppl 4:231-5. CrossRef

17. Neal JM, Gerancher JC, Hebl JR, Ilfeld BM, McCartney CJ, Franco $C D$, et al. Upper extremity regional anesthesia: essentials of our current understanding, 2008. Reg Anesth Pain Med 2009;34(2):134-70. CrossRef

18. Neal JM, Moore JM, Kopacz DJ, Liu SS, Kramer DJ, Plorde JJ. Quantitative analysis of respiratory, motor, and sensory function after supraclavicular block. Anesth Analg 1998;86(6):1239-44. CrossRef

19. Brown DL, Cahill DR, Bridenbaugh LD. Supraclavicular nerve block: anatomic analysis of a method to prevent pneumothorax. Anesth Analg 1993;76(3):530-4. CrossRef

20. Hsu DT. Cardiac manifestations of neuromuscular disorders in children. Paediatr Respir Rev 2010;11(1):35-8. CrossRef 